\title{
Studi meta analisis: Small effect size pada korelasi antara dukungan sosial dan penyesuaian diri
}

\author{
Dedi Nasruddin ${ }^{1}$ dan Ananta Yudiarso ${ }^{2}$
}

\begin{abstract}
The purpose of this study was to statistically test the effect size correlation between social support and adjustment using meta-analysis. This study uses a meta-analysis of literature reviews of 16 international research journals. The total of participants was 4,475. Researchers followed the guidelines from PRISMA and MARS. Using statistical analysis of effect size correlation ( $r$-value and sample size) $(\mathrm{N})$, We found a small effect size correlation. The effect size value obtained from the random effect $r=0.149(\mathrm{Cl}=-0.006$ to 0.304$), \mathrm{I}^{2}$ (inconsistency) $=96.29 \%$. Our findings indicated that social support and adjustment had a direct small effect size.
\end{abstract}

\section{Keywords}

Adjustment, meta analysis, social support

\section{Pendahuluan}

Penyesuaian diri merupakan proses yang tidak pernah lepas dari kehidupan manusia, terutama saat menghadapi perubahan. Proses penyesuaian diri dengan lingkungannya tersebut dilakukan agar kehiudupannya yang dinamis menjadi lebih seimbang (Santrock, 2013). Oleh karenanya, manusia akan terus berusaha melakukan penyesuaian diri. Menurut Brady-Amoon \& Fuertes (2011) penyesuaian diri merupakan bagaiamana seseorang mampu mengharmonisasikan dirinya sendiri dengan orang lain dan segala elemen yang berada disekitarnya. Mendukung hal tersebut, Semiun (2010) menyatakan bahwa penyesuaian diri merupakan kemampuan seseorang dalam beradaptasi, berafeksi, penerapan kehidupan yang seimbang, kemampuan dalam pengambilan keputusan, kemampuan toleransi terhadap frustasi, sikap humor, sikap yang ekstrem, serta sikap objektif.

Proses penyesuaian diri akan menghasilkan sebuah perilaku yang sesuai dengan harapan masyarakat di lingkungan. Rasmussen (2015) menyatakan bahwa penyesuaian diri merupakan proses pemuasaan keputusan dan keterampilan dalam menangani sebuah konflik ketegangan atau masalah. Proses penyesuaian diri tentunya akan berhubungan langsung dengan lingkungan sosial. Ekanita \& Putri (2019) dalam penelitiannya memperlihatkan bahwa terdapat hubungan positif antara dukungan sosial dan penyesuaian diri individu.

Penyesuaian diri yang baik dapat terjadi jika seorang individu mendapat dukungan dari keluarga, teman, dan orang terdekat. Baron \& Byrne (2012) menyebutkan bahwa dukungan sosial merupakan suatu perasaan nyaman baik secara fisik maupun secara psikologis yang didapatkan dari orang lain. Dengan adanya dukungan dari orang lain maka proses penyesuaian diri seseorang akan semakin baik atau akan semakin cepat dalam memperlihatkan pola tindakan yang sesuai dengan norma dan aturan. Sumber dukungan sosial dapat diperoleh dari berbagai arah seperti orang tua, guru, teman kuliah, dan bahkan kelekatan institusi (Rahayu \& Arianti, 2020).

Sarafino \& Smith (2011) menyatakan dukungan sosial merupakan suatu kondisi individu yang merasakan kenyamanan, kepedulian, penghargaan serta bantuan yang diberikan oleh orang lain ketika individu membutuhkan. Seseorang yang mendapatkan dukungan sosial, mereka percaya bahwa mereka merasa dicintai, dihargai dan menjadi bagian dari lingkungannya sehingga mereka bisa adjust dengan lingkungannya. Namun demikian dukungan sosial dapat juga berbentunya sebaliknya yaitu hubungan yang tidak sehat sebagai salah satu determinannya (Hanton, 2011). Individu yang kehilangan teman akrab dan berada di lingkungan yang kurang peduli, maka individu tersebut merasakan kesedihan secara emosional serta merasa sangat kehilangan.

Telah banyak dilakukan penelitian hubungan antara dukungan sosial dan penyesuaian diri. Hubungan yang signifikan antara dukungan sosial dengan penyesuaian diri pada individu ditemukan pada beberapa riset terdahulu (Yagmur \& Duman, 2016; Safareka et al., 2018; ?; Gudmundsdottir et al., 2019; Nunes et al., 2021).

\section{${ }^{1,2}$ Universitas Surabaya}

Korespondensi:

Dedi Nasruddin, Fakultas Psikologi Universitas Surabaya

Email: dedinasruddin6@gmail.com 
Lau et al. (2018) membuktikan bahwa individu yang menerima dukungan keluarga dan teman sebaya yang lebih besar melaporkan hasil penyesuaian diri yang lebih baik secara keseluruhan. Selain menjadi salah satu faktor yang mempengaruhi penyesuaian diri seseorang, dukungan sosial juga merupakan salah satu faktor yang paling signifikan dalam meminimalkan depresi, kesepian dan kecemasan pada siswa yang mengalaman ketidakbisaan menyesuaikan diri (Nisa et al., 2018).

Individu diterima secara positif di lingkungannya maka ia akan lebih mudah dalam proses melakukan penyesuaian diri. Menurut riset terdahulu penyesuaian diri merupakan salah satu bekal penting pada saat terjun ke masyarakat luas, serta dapat menjadi persyaratan penting bagi terciptanya kesehatan jiwa dan mental individu (Rachyla et al., 2018). Disisi lain, ada temuan yang berbeda bahwa dukungan sosial tidak selalu memiliki hubungan yang positif terhadap penyesuaian diri (Wicaksono, 2019; Savitri \& Purwaningtyastuti, 2017; Sa'idah \& Laksmiwati, 2017; Mega, 2013; Wijaya \& Prastitis, 2012). Semakin tinggi dukungan sosial yang didapatkan dari keluarga belum tentu dapat membuat seseorang semakin baik dalam menyesuaikan diri dengan lingkungannya. Oleh kareanya untuk melihat secara menyeluruh pola hubungan antara dukungan sosial dan penyesuaian diri perlu menghimpun berbagai penelitian terdahulu sebagai basis bukti. Cara menghimpun berbagai temuan studi terdahulu tersebut dapat dilakukan dengan studi meta analisis.

Retnawati et al. (2018) Studi meta-analisis merupakan suatu teknik statistika yang menggabungkan dua atau lebih penelitian sejenis sehingga diperoleh paduan data secara kuantitatif. Pada studi meta-analisis tidak fokus pada kesimpulan hasil penelitian, namun berfokus pada data studi dari penelitian tersebut. Berdasarkan dari uraian diatas maka, terdapat dua hal alasan utama peneliti melakukan meta-analisis.

Pertama adalah temuan yang tidak konsisten pada penelitian sebelumnya, yaitu dukungan sosial dianggap berkorelasi positif dengan penyesuaian diri individu (Yagmur \& Duman, 2016; Safareka et al., 2018; ?; Gudmundsdottir et al., 2019; Nunes et al., 2021) dan temuan yang berlawanan menyatakan tidak berkorelasi positif (Wicaksono, 2019; Savitri \& Purwaningtyastuti, 2017; Sa'idah \& Laksmiwati, 2017). Kedua, peneliti memandang perlu untuk menyatukan dan membuat kesimpulan secara statistik dengan menggunakan meta analisis untuk mendapat hasil secara menyeluruh dari studi yang menghubungkan dukungan sosial dan penyesuaian diri. Pada studi meta-analisis tidak fokus pada kesimpulan hasil penelitian, namun berfokus pada data studi dari penelitian tersebut (Retnawati et al., 2018)

\section{Metode}

Penelitian ini menggunakan metode meta-analysis, pada proses penelitian ini memanfaatkan hasil yang ditemukan oleh penelitian-penelitian terdahulu. Pada penelitian ini terlebih dahulu menentukan dukungan sosial dan penyesuaian diri sebagai variabel yang hendak diteliti. Kemudian peneliti mencari, mengumpulkan dan menyeleksi sejumlah jurnal penelitian terdahulu yang telah ditentukan dengan kriteria penelitian 10 tahun terakhir dan jurnal internasional, serta tahap terakhir peneliti mengukur effect size antara social support dan adjustment.

Pengolahan data menggunakan Jamovi app (version 1.6) (The jamovi project , 2020). Data yang dimasukkan adalah nama penulis, tahun publikasi, koefisien korelasi (r) antara social support dengan adjustment dan jumlah sampel yang terlibat. Meta-analisis ini berbasis effect size nilai $\mathrm{r}$, dikatakan small effect size jika $\mathrm{r}=0.1$, medium effect size jika $\mathrm{r}=0.3$ serta large effect size jika $\mathrm{r}=0.5$ (Cooper et al., 2019)

Penelitian ini akan melihat effect size korelasi social support dalam adjustment. Effect size dilihat dari nilai korelasi (r) serta ukuran sampel (N) Heterogenitas penelitian didapat dari nilai I2. dengan semakin besar nilai yang dihasilkan maka menunjukkan keragaman hasil. Penulisan ini menggunakan panduan penulisan PRISMA dan MARS.

Sumber database yang ditelusuri untuk mencari penelitian-penelitian terdahulu adalah ScienceDirect. Emerald Insight. Research Gate. ProQuest dan Springer Link. dengan kata kunci yang digunakan adalah social support and adjustment. Pencarian jurnal menggunakan kata kunci bahasa Inggris dan pemilihan jurnal terbatas pada jurnal internasional. Setelah proses pemilihan jurnal, maka didapatkan 13 jurnal utama yang akan diolah dengan tahun publikasi antara tahun 2013-2020. Jurnal yang digunakan menunjukkan data hasil koefisien korelasi (r) dan jumlah sampel (N). Proses penelusuran tersebut dapat digambarkan dalam diagram dibawah ini:

Gambar 1 merupakan skema penelusuran jurnal internasional. Terdapat 859.851 jurnal yang ditemukan dengan menggunakan kata kunci social support and adjustment, kemudian di-scanning dengan kata kunci hubungan dukungan sosial dan penyesuaian diri mendapatkan hasil 60 jurnal. Proses scanning akhir mendapatkan total jurnal sebanyak 13 jurnal internasional, dengan kriteria jurnal tahun 2013-2020, jurnal internasional tersebut mencantumkan nilai korelasi (r) serta ukuran sampel (N).

\section{Hasil}

Tabel 1 menunjukkan perhitungan statistik melalui analisis korelasi effect size. Hasil menunjukkan dukungan sosial mempengaruhi penyesuaian diri individu. Berdasarkan pengolahan data $\mathrm{r}$ dan $\mathrm{N}$ ditemukan nilai effect textitsize small yang diperoleh dari random effect yaitu sebesar 0.149 (CI $=-0.006$ sampai $0.304, \mathrm{P}=0.059$ dengan $\mathrm{I}^{2}$ (inconsistency) $=96.29 \%)$, serta eiger bias $\mathrm{P}=0.235$. Dengan demikian, hasil ini mengimplikasikan bahwa dukungan sosail memiliki hubungan kecil secara langsung dengan penyesuaian diri. 


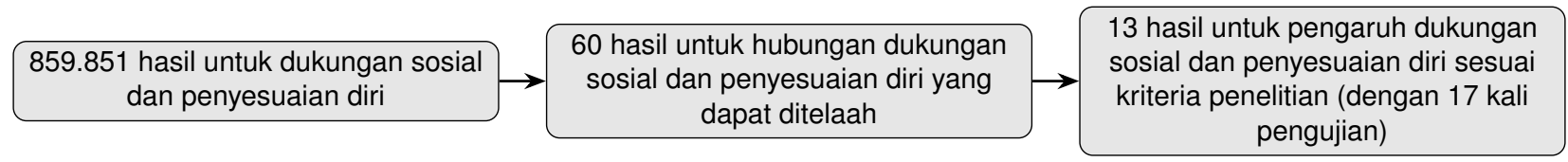

Gambar 1. Skema penelusuran jurnal data meta analisis

Tabel 1. Hasil Analisis Jurnal Penelitian Menggunakan Jamovi App (Version 1.6)

\begin{tabular}{|c|c|c|c|c|c|c|}
\hline \multirow[b]{2}{*}{ Peneliti } & \multirow[b]{2}{*}{ Negara } & \multicolumn{2}{|c|}{ Alat Ukur } & \multirow[b]{2}{*}{$r$} & \multirow[b]{2}{*}{$\mathrm{N}$} & \multirow[b]{2}{*}{$95 \% \mathrm{Cl}$} \\
\hline & & Dukungan sosial & Penyesuaian diri & & & \\
\hline Lee. et.al. (2013) & Taiwan & Social Support Scale & Expatriate Adjustment Scale & 0.02 & 156 & $(-0.14)-0.18$ \\
\hline $\begin{array}{l}\text { Parera. et.al. } \\
(2015)\end{array}$ & Australia & $\begin{array}{l}\text { Social Provisions Scale } \\
\text { (SPS) }\end{array}$ & $\begin{array}{l}\text { Trait Emotional Intelligence } \\
\text { Questionnaire-Short-Form } \\
\text { (TEIQUE-SF) }\end{array}$ & 0.64 & 470 & $0.67-0.85$ \\
\hline $\begin{array}{l}\text { Marhamah. et.al. } \\
\text { (2016) }\end{array}$ & Malaysia & $\begin{array}{l}\text { Mutlidimensional Scale Of } \\
\text { Perceived Social Support } \\
\text { (MSPSS) }\end{array}$ & $\begin{array}{l}\text { Student Life Stress } \\
\text { Inventory (SLSI) }\end{array}$ & -0.46 & 364 & $(-0.60)-(-0.39)$ \\
\hline $\begin{array}{l}\text { Yagmur. et.al.. } \\
(2016) \text {. }\end{array}$ & Turkey & $\begin{array}{l}\text { Multidimensional Scale of } \\
\text { Perceived Social Support } \\
\text { (MSPSS) }\end{array}$ & $\begin{array}{l}\text { Mental Adjustment To } \\
\text { Cancer (MAC) Scale } \\
\text { [Fighting Spirit] }\end{array}$ & 0.34 & 190 & $0.21-0.50$ \\
\hline $\begin{array}{l}\text { Yagmur. et.al. } \\
(2016)\end{array}$ & Turkey & $\begin{array}{l}\text { Multidimensional Scale of } \\
\text { Perceived Social Support } \\
\text { (MSPSS) }\end{array}$ & $\begin{array}{l}\text { Mental Adjustment To } \\
\text { Cancer (MAC) Scale } \\
\text { [Hopelessness] }\end{array}$ & -0.25 & 190 & $(-0.40)-(-0.11)$ \\
\hline $\begin{array}{l}\text { Yagmur. et.al.. } \\
(2016) .\end{array}$ & Turkey & $\begin{array}{l}\text { Multidimensional Scale of } \\
\text { Perceived Social Support } \\
\text { (MSPSS) }\end{array}$ & $\begin{array}{l}\text { Mental Adjustment To } \\
\text { Cancer (MAC) Scale } \\
\text { [Fatalism] }\end{array}$ & -0.20 & 190 & $(-0.35)-(-0.06)$ \\
\hline $\begin{array}{l}\text { Asraf. et.al.. } \\
(2018)\end{array}$ & Pakistan & $\begin{array}{l}\text { Multidimensional Social } \\
\text { Support Scale (MSSS) }\end{array}$ & $\begin{array}{l}\text { Psychological Adjustment } \\
\text { Illness Scale Self Reflection } \\
\text { (PAIS-SR) }\end{array}$ & 0.33 & 100 & $0.14-0.54$ \\
\hline $\begin{array}{l}\text { Gudmundsdottir. } \\
\text { et.al.. (2018) }\end{array}$ & Iceland & $\begin{array}{l}\text { Index of Sojourner Social } \\
\text { Support (ISSS) }\end{array}$ & $\begin{array}{l}\text { Spousal Adjustment 7-Point } \\
\text { Scale }\end{array}$ & 0.31 & 246 & $0.19-0.45$ \\
\hline Mert. (2018) & Turkey & $\begin{array}{l}\text { The Mutlidimensional Scale } \\
\text { of Perceived Social Support } \\
\text { (MSPSS) }\end{array}$ & $\begin{array}{l}\text { Dyadic Adjustment Scale } \\
\text { (SDS) }\end{array}$ & 0.01 & 422 & $(-0.09)-0.11$ \\
\hline Medina. (2018) & Filipina & $\begin{array}{l}\text { Interpersonal Sopport } \\
\text { Evaluation List (ISEL) }\end{array}$ & $\begin{array}{l}\text { College Adjustment Tes } \\
\text { (CAT) }\end{array}$ & 0.02 & 377 & $(-0.08)-0.12$ \\
\hline $\begin{array}{l}\text { Lashari. et.al.. } \\
\text { (2018) }\end{array}$ & Malaysia & $\begin{array}{l}\text { Mutlidimensional Scale of } \\
\text { Perceived Social Support } \\
\text { (MSPSS) }\end{array}$ & $\begin{array}{l}\text { Student Adaptation To } \\
\text { College Questionnaire }\end{array}$ & 0.22 & 200 & $0.08-0.36$ \\
\hline $\begin{array}{l}\text { Gudmundsdottir. } \\
\text { et.al.. (2019) }\end{array}$ & EUFASA & $\begin{array}{l}\text { Index of Sojourner Social } \\
\text { Support (ISSS) }\end{array}$ & $\begin{array}{l}\text { Spousal Adjustment Was } \\
\text { Measured Using A Scale. }\end{array}$ & 0.49 & 268 & $0.42-0.66$ \\
\hline Nho. et.al.. (2019) & Korea & $\begin{array}{l}\text { 9-Item of Children's Social } \\
\text { Support Scale }\end{array}$ & A School-Adjustment Scale & 0.59 & 65 & $0.43-0.93$ \\
\hline Shu. et.al.. (2020) & U.S & $\begin{array}{l}\text { Multidimensional Scale of } \\
\text { Perceived Social Support } \\
\text { (MSPSS) }\end{array}$ & $\begin{array}{l}\text { Students Rated Their Level } \\
\text { of Adjustment on A 14-Item } \\
\text { Scale (General Adjustment) }\end{array}$ & 0.03 & 276 & $(-0.09)-0.15$ \\
\hline Shu. et.al.. (2020) & U.S & $\begin{array}{l}\text { Multidimensional Scale of } \\
\text { Perceived Social Support } \\
\text { (MSPSS) }\end{array}$ & $\begin{array}{l}\text { Students Rated Their Level } \\
\text { of Adjustment on A 14-Item } \\
\text { Scale (Interaction } \\
\text { Adjustment) }\end{array}$ & 0.08 & 276 & $(-0.04)-0.20$ \\
\hline Shu. et.al.. (2020) & U.S & $\begin{array}{l}\text { Multidimensional Scale of } \\
\text { Perceived Social Support } \\
\text { (MSPSS) }\end{array}$ & $\begin{array}{l}\text { Students Rated Their Level } \\
\text { of Adjustment on A 14-Item } \\
\text { Scale (School-Related } \\
\text { Adjustment) }\end{array}$ & 0.02 & 276 & $(-0.10)-0.14$ \\
\hline $\begin{array}{l}\text { Nunes. at.al.. } \\
(2020)\end{array}$ & Portugal & $\begin{array}{l}\text { The Duke-Unc Functional } \\
\text { Social Support }\end{array}$ & $\begin{array}{l}\text { Strengths And Difficulties } \\
\text { Questionnaire (SDQ) }\end{array}$ & 0.15 & 409 & $0.05-0.25$ \\
\hline
\end{tabular}

*Tested with the parametric hypothesis test (paired sample t-test).

Gambar 2 menunjukkan perhitungan statistik melalui analisis korelasi effect size. Hasil menunjukkan effect size meta-analysis plot random effect dukungan sosial dalam penyesuaian diri. Berdasarkan pengolahan data $r$ dan $\mathrm{N}$ ditemukan nilai effect size secara umum yaitu 0.15 sehingga berada pada kategori yang kecil. 


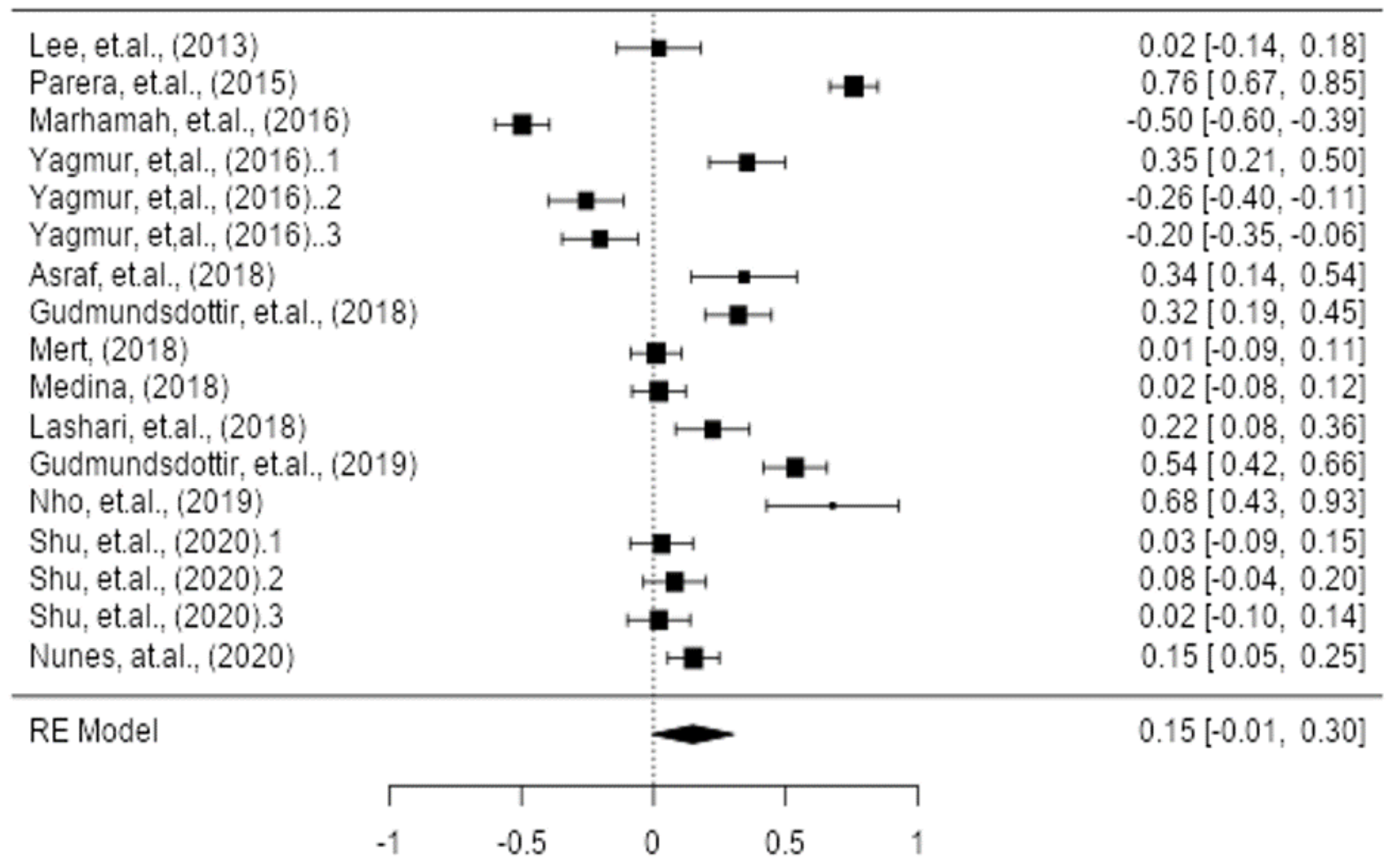

Gambar 2. Effect size meta-analysis plot random effect

Tabel 2. Publication Bias Assessment

\begin{tabular}{lrr}
\hline Test Name & \multicolumn{1}{c}{ Value } & \multicolumn{1}{c}{$\mathrm{p}$} \\
\hline Fail-Safe N & 298.000 & $<0.001$ \\
Kendalls Tau & 0.238 & 0.562 \\
Egger's Regression & 0.921 & 0.235 \\
\hline
\end{tabular}

Note. Fail-safe N Calculation Using the Resenthal Approach

Tabel 2 menunjukkan hasil publication bias assessment pengolahan data menggunakan The Jamovi app version 1.6 pada jurnal yang digunakan. Penelitian ini juga memperlihatkan nilai eiger bias $\mathrm{P}$ sebesar 0.235 , hasil ini memperlihatkan bahwa tidak ada bias penelitian yang terjadi di jurnal internasional yang digunakan. Bias merupakan kesalahan sistematis dalam penelitian termasuk didalam kesalahan sampling atau bias dalam sampling dan bias dalam teknik pengumpulan data yang menyebabkan incorrect estimates terkait hubungan kedua variabel yaitu dukungan sosial dan penyesuaian diri. Artinya jurnal yang digunakan cukup baik sehingga layak untuk dijadikan sumber data sebagai acuan dasar penelitian meta-analisis.

\section{Pembahasan}

Berdasarkan pengolahan data dengan menggunakan metode meta-analysis, ditemukan nilai random effect yaitu sebesar 0.149. Nilai tersebut masuk dalam kategori small effect size atau dengan kata lain bahwa hipotesis yang berbunyi terdapat nilai large effect size korelasi antara dukungan sosial dan penyesuaian diri ditolak. Hasil tersebut tetap memperlihatkan adanya korelasi yang signifikan antara dukungan sosial dan penyesuaian diri, hanya saja nilai korelasinya kecil. Secara empiris, terdapat bukti hasil penelitian menunjukkan adanya hubungan yang signifikan antara dukungan sosial dan penyesuaian diri (Yagmur \& Duman, 2016; Safareka et al., 2018; Lau et al., 2018; Gudmundsdottir et al., 2019; Nunes et al., 2021).

Santrock (2013) mengatakan bahwa ketika individu mendapatkan penolakan dari lingkungannya dan tidak mendapatkan dukungan sosial maka individu tersebut akan menghasilkan penyesuaian diri yang kurang baik (kesulitan untuk menyesuaikan dengan kondisi lingkungannya). Kumalasari \& Ahyani (2012) menyatakan semakin tinggi dukungan sosial individu maka semakin tinggi penyesuaian duru pada individu tersebut dan begitupun sebaliknya. Namun, pada penelitian ini memperlihatkan hasil korelasi antara dukungan sosial dan penyesuaian diri dengan nilai small effect size. Nilai tersebut bukan berarti tidak adanya korelasi antara kedua variabel yang diteliti, namun demikian maksud dari small effect size adalah memperlihatkan adanya korelasi secara direct dengan ukuran yang kecil.

Hasil small effect size pada penelitian ini disebabkan oleh beberapa faktor. Salah satu faktornya adalah penelitian ini menganalisis data dengan menggunakan beberapa alat ukur yang berbeda-beda, baik antara 
dukungan sosial maupun penyesuaian diri. Alat ukur yang digunakan untuk dukungan sosial yaitu MSPSS (9 kali), ISSS (2 kali), SSS, SPS, MSSS, ISEL, 9 item CSSS, serta The Duke Function Social Support. Sedangkan untuk penyesuaian diri menggunakan alat ukur yang berbedabeda pula, mulai dari Expatriate Adjustment Scale, TEIQUE-SF, SLSI, MAC, PAIS-SR, Spousal Adjustment 7Point Scale, Student Adaptation to College Questionnaire, $S D Q, C A T$ dan lain sebagainya. Alat ukur yang digunakan bukan hanya berbeda, tetapi juga terdapat perbedaan karakter sampel serta jenis dukungan sosial yang diterima berbeda oleh setiap sampel penelitian, mulai dari dukungan keluarga, teman serta lingkungan yang berbeda pula.

Penelitian ini juga memperlihatkan sumber data korelasi yang memiliki arah korelasi berlawanan (korelasi negatif dan korelasi positif). Sumber data yang memiliki korelasi negatif yaitu Marhamah \& Hamzah (2016) dan Yagmur \& Duman (2016). Hasil penelitian Marhamah \& Hamzah (2016) memperlihatkan bahwa semakin tinggi tekanan dari lingkungan (misalnya beban kuliah) individu maka semakin rendah penyesuaian diri pada individu tersebut. Kondisi sumber dukungan sosial yang berbeda akan sangat mempengaruhi perilaku individu tersebut, sehingga secara tidak langsung akan mempengaruhi pula pola penyesuaian drinya terhadap lingkungan. Penelitian ini memperlihatkan bahwa terdapat sumber dukungan yang belum tentu menjadikan individu lebih mampu melakukan penyesuaian diri dengan lingkungannya. Dengan kata lain, seseorang akan mudah adjust ketika mendapat sumber dukungan yang tepat untuk kondisinya saat itu.

Berdasarkan uraian diatas, maka peneliti menyatakan bahwa nilai small effect size yang diperoleh sangat dipengaruhi oleh alat ukur yang berbeda, situasi dan kondisi sampel yang berbeda serta sumber dukungan sosial. Pada penelitian meta-analysis selanjutnya dengan topik serupa, disarankan untuk melakukan kajian literatur review dengan mempertimbangkan batasan populasi penelitian misalnya pada sampel dengan kelompok usia tertentu, kondisi lingkungan yang berbeda (sumber dukungan sosial), serta perlu diperhatikan perbedaan alat ukur yang digunakan. Dengan demikian dapat diperoleh informasi efektif antara perbedaan subjek penelitian dan sumber dukungan sosial yang menjadi acuan utama, baik itu sumber dukungan yang berasal dari lingkungan keluarga, teman atau bahkan dari sumber yang lain.

\section{Kesimpulan}

Hasil penelitian ini berdasarkan small effect size membuktikan adanya korelasi secara direct antara dukungan sosial dan penyesuaian diri dengan ukuran yang kecil. Seseorang akan lebih mampu melakukan penyesuaian diri ketika mendapatkan sumber dukungan yang sesuai dengan kebutuhannya pada kondisi yang dihadapi. Sumber dukungan sosial setiap individu berbeda antara satu dengan lainnya bergantung kepada situasi dan kondisi masing-masing serta kebutuhannya.
Penelitian menggunakan metode meta-analisis dengan melibatkan berbagai jurnal penelitian terdahulu yang dilakukan oleh peneliti memiliki keterbatasan yaitu peneliti tidak mengkategorikan atau memisahkan sumber dukungan sosial yang diterima oleh subjek penelitian. Selain itu, penelitian ini masih belum dapat memetakan proses penyesuaian diri individu secara menyeluruh dengan adanya keterlibatan dari variabel lain seperti variabel moderator seperti (jenis kelamin, usia, pendidikan serta sosial ekonomi) yang turut berkontribusi didalamnya. Berdasarkan keterbatasan penelitian ini diharapakan pada peneliti berikutnya untuk dapat lebih komprehensif dan memetakan bagaimana pola hubungan dari kedua variabel yang diteliti.

\section{Reference}

Asraf, S., Ambreen, I., \& Shah, M. (2018). Effects of social support on psycho-social adjustment of patients with breast cancer in setting of Lahore Pakistan. Biomedical Journal of Scientific and Technical Reasearch, 3(3). 3225- 3232. https: //doi.org/10.26717/BJSTR.2018.03.000891

Baron, R.A., \& Byrne, D. (2012). Psikologi sosial jilid 2 (edisi kesepuluh) alih bahasa: Ratna Juwita. Jakarta: Erlangga.

Brady-Amoon, P., \& Fuertes, J. N. (2011). Self-efficacy, selfrated abilities, adjustment, and academic performance. Journal of Counseling \& Development, 89(4), 431-438. https://doi.org/10.1002/j.1556-6676.2011.tb02840.x

Core, R., \& Team. (2020). R: A Language and environment for statistical computing. (Version 4.0) [Computer software]. Retrieved from https://cran.r-project.org. (R packages retrieved from MRAN snapshot 2020-08-24).

Cooper, H., Larry V. H., \& Jeffrey C.V. (2019) The handbook of research synthesis and meta-analysis. Russell Sage Foundation. Interpreting Effect Sizes: 435.

Ekanita, A., \& Putri, D.R. (2019). Hubungan antara dukungan sosial dengan penyesuaian diri santriwati kelas VII Madrasah Tsanawiyah (MTs) Pondok Pesantren di Sukoharjo. Psikologika: Jurnal Pemikiran dan Penelitian Psikologi, 24(2), 149-154. https://doi.org/10.20885/ psikologi.vol24.iss2.art5

Gudmundsdottir, S., Gudlaugsson, T.O., \& Adalsteinsson, G.D. (2019). The diplomatic spouse relationships between adjustment, social support and satisfaction with Life. Journal of Global Mobility, 7(1), 103-122. https://doi.org/10.1108/ JGM-09-2018-0043.

Hanton, P. (2011). Skills in solution focused brief: Counselling \& psychotherapy. SAGE Publications Ltd, https://www.doi. org/10.4135/9781446251980

The jamovi project. (2020). jamovi. (Version 1.6) [Computer Software]. Retrievedfromhttps://www.jamovi.org.

Kumalasari, F., \& Ahyani, L.N. (2012). Hubungan antara dukungan sosial dengan penyesuaian diri remaja di panti asuhan. Jurnal Psikologi Pitutur 1(1), 21-31. https://jurnal. umk.ac.id/index.php/PSI/article/view/33/32 
Lashari, A.A., Kaur, A., \& Hashim, R.A. (2018). Home away from home - the role of social support for international students' adjustment. Malaysian Journal of Learning and Instruction 15(2), 33-54. https://eric.ed.gov/?id=EJ1201660

Lau, E. Y. H., Chan, K. K. S., \& Lam, C. B. (2018). Social support and adjustment outcomes of firstyear university students in hong kong: self-esteem as a mediator. Journal of College Student Development, 59(1). https://doi.org/10.1353/ csd.2018.0011

Lee, L., Veasna, S., \& Wu, W. (2013). The effects of social support and transformational leadership on expatriate adjustment and performance. Journal Career Development International, 18(4), 377 - 415. https://doi.org/10.1108/CDI06-2012-0062

Marhamah, F., \& Hamzah, H.B. (2016). The relationship between social support and academic stress among first year students at Syiah Kuala University. Jurnal Psikoislamedia, 1(1), 149172. http://dx.doi.org/10.22373/psikoislamedia.v1i1.1487

Medina, M.S.G. (2018). The self-esteem, social support and college adjustment of business and accountancy students. Review of Integrative Business and Economics Research, 7(2)167-175. https://sibresearch.org/uploads/3/4/ 0/9/34097180/riber_7-s2_k18-042_167-175.pdf.

Mega, A. (2013). Hubungan antara dukungan sosial dari orang tua dengan penyesuaian diri santri Pondok Pesantren ANNUR 2 Al Murtadlo Malang. Psikoislamika, 10(2), 34-41. https: //doi.org/10.18860/psi.v10i2.6369

Mert, A. (2018). The predictive role of values and perceived social support variables in marital adjustment. Universal Journal of Educational Research, 6(6), 1192-1198, https: //doi.org/10.13189/ujer.2018.060609

Nho, C.R., Yoon, S., Seo, J., \& Cui, L. (2019). The mediating effect of perceived social support between depression and school adjustment in refugee children in south Korea. Journal Children and Youth Services Review, 106 (2019) 104474. https://doi.org/10.1016/j.childyouth.2019.104474

Nisa, K., Tiatri, S., \& Mularsih, H. (2018). Peran dukungan teman sebaya dan regulasi diri belajar terhadap penyesuaian akademis mahasiswa perguruan tinggi kedinasan berasrama xyz. Jurnal Muara Ilmu Sosial, Humaniora, dan Seni, 2(1), 318-328. http://dx.doi.org/10.24912/jmishumsen.v2i1.1641

Nunes, C., Martins, C., Ayala-Nunes, L., Matos, F., Costa, E., \& Gonçalves, A. (2021). Parents' perceived social support and children's psychological adjustment. Journal of Social Work, 21(3), 497-512. https://doi.org/10.1177/1468017320911614

Parmaksiz, I. (2019). Assertiveness as the predictor of adjustment to university life amongst university students. International Journal of Instruction, 12(4), 131-148. http://dx.doi.org/10. 29333/iji.2019.1249a

Perera, H. N., \& DiGiacomo, M. (2015). The role of trait emotional intelligence in academic performance during the university transition: An integrative model of mediation via social support, coping, and adjustment. Personality and Individual Differences, 83, 208-213. https://doi.org/10.1016/ j.paid.2015.04.001
Rahayu, M.N.M., \& Arianti, R. (2020). Penyesuaian mahasiswa tahun pertama di perguruan tinggi: Studi pada mahasiswa fakultas psikologi uksw. Jurnal Psikologi Sains dan Profesi. 4(2), 73 - 84. https://doi.org/10.24198/jpsp.v4i2.26681

Rachyla, I., Perez-Ara, M., Moles, M., Campos, D., Mira, A., \& Botella, C. (2018). An internet-based intervention for adjustment disorder (TAO): Study 15 protocol for a randomized controlled trial. BMC Psychiatry, 18(1), 1-10. https://doi.org/10.1186/s12888-018-1751-6

Rasmussen, B. (2015). A Psychodynamic perspective on assessment and formulation. In B. Probst (Ed.), Essential Clinical Social Work Series. Critical thinking in clinical assessment and diagnosis (p. 151-169). Springer International Publishing $\mathrm{AG}$.

Retnawati, H., Apino, E., Djidu, H., \& Anazifa, R. D. (2018). Pengantar analisis meta. Yogyakarta: Parama Publishing.

Safareka, Y., Setyowani, N., \& Anni, C. T. (2018). Penyesuaian diri siswa dilihat dari segi konsep diri dan dukungan sosial pada siswa SMP. Indonesian Journal of Guidance and Counseling: Theory and Application, 7(2), 61-67. https://doi. org/10.15294/ijgc.v7i2.18142

Sa'idah, S., \& Laksmiwati, H. (2017). Dukungan sosial dan selfefficacy dengan penyesuaian diri pada santri tingkat pertama di pondok pesantren. Jurnal Psikologi Teori dan Terapan, 7(2), 116-122. https://doi.org/10.26740/jptt.v7n2.p116-122

Santrock, J.W. (2013). Life span development Edisi 13 Jilid 2. Jakarta: Erlangga.

Sarafino, E. P., \& Smith, T. W. (2011). Health Psychology: Biopsychological Interactions 7th Edition. United Stated: Library of Congress Cataloging in Publication Data.

Savitri, A. D., \& Purwaningtyastuti. (2017). Penyesuaian diri orang dengan HIV dan AIDS (ODHA) ditinjau dari dukungan sosial. Philantrophy Journal of Psychology, 1(1), 17-25. http://dx.doi.org/10.26623/philanthropy.v1i1.773

Semiun, Y. (2010). Kesehatan Mental 3. Yogyakarta: Kasisius.

Shu, F., Ahmed, S.F., Pickett, ML., \& Ayman, R. (2020). Social support perceptions, network characteristics, and international student adjustment. International Journal of Intercultural Relations, 74(2020), 136-146. https://doi.org/ 10.1016/j.jintrel.2019.11.002.

Wicaksono, F.S. (2019). Hubungan antara dukungan sosial keluarga dengan penyesuaian diri pada siswa Smk Pelita Nusantara 2 Semarang. USM Scinece. Skripsi. Universitas Semarang.

Wijaya, I. P., \& Prastitis, N. T. (2012). Efikasi diri akademik, dukungan sosial orangtua dan penyesuaian diri mahasiswa dalam perkuliahan. Jurnal Persona,1(1), 40-52. https://doi. org/10.30996/persona.v1i1.14

Yagmur. Y., \& Duman, M. (2016). The relationship between the social support level perceived by patients with gynecologic cancer and mental adjustment to cancer. International Journal of Gynecology and Obstetrics, xxx (2016) xxx-xxx. https://doi.org/10.1016/j.ijgo.2015.12.010 